\title{
Training Analysis of Management of Creative Classes in Disruption Era
}

\author{
Fitria Hanaris \\ Department of Education Management \\ Universitas Negeri Surabaya \\ Surabaya, Indonesia \\ Fitriahanaris.18001@mhs.unesa.ac.id
}

\begin{abstract}
The purpose of this research is to give educators insight into creative and effective classroom management skills, giving learners a sense of comfort and fun. The training used a system approach with a sample of 6 class teachers at Klapayan 3 Elementary School. The results of the study stated that classroom management and creative teaching in the disruption Era prioritizes multimedia utilization as a means of learning.In addition, the barriers were found as the absence of availability of multimedia facilities in the school, a narrow classroom, and a pedagogic competence of low teachers.
\end{abstract}

Keywords—training analysis; creative classroom management; era disruption

\section{INTRODUCTION}

The 21 st century is marked as a century of openness or the age of globalization, meaning that human life in the $21 \mathrm{st}$ century experiences fundamental changes that are different from the order of life in the previous century. It is said that the 21 st century is a century that demands quality in all efforts and results of human labor. The 21 st century also asks for quality human resources, which are produced by professionally managed institutions that produce superior results. These new demands demand various breakthroughs in thinking, drafting, and actions. In other words a new paradigm is needed in the face of new challenges, said philosopher Khun. According to Khun philosopher when the new challenges are faced using the old paradigm, all attempts will meet the failure [1]. Similarly, the challenges on the system must adapt to the age of development, so that education must immediately adapt to the development of this increasingly sophisticated era [2].

To adjust the education with the development of the current era, it must have a quality output and can compete with the acceleration of extraordinary knowledge enhancement. his accelerated increase in knowledge is supported by the adoption of today's emerging digital media and technologies. Learning activities must be adapted between knowledge and needs at this time. Learning materials should provide a more authentic design for the challenges that learners can collaborate on to create solutions to solve lesson problems. According to Gagne "defines problem solving as a process of synthesizing various concepts, rules, or formulas to solve the problem" [3]. Problem solving leads to questions and seeking answers by learners who can then be sought to solve problems in the context of learning using information resources for media implementation and digital technology.

For the creation of authentic learning, there are demands for the development of learning devices (tools), leaving conventional learning methods and models, and innovating so that the delivery of learning is more practical and useful. Learning will be comfortable and enjoyable if the treatment varies according to the style and intellect that learners have, because the intelligence and ability of each student is different in understanding a subject, so it differs the experience gained [4]. The curriculum organization is formed in the pattern, design, content, and materials integrated in the effort to provide facilities for educators and students to implement it in order to create a comfortable and enjoyable learning atmosphere. The curriculum is organized and the whole series of learning become more directed and become a source of learning activities to transfer cultural, social, science and technology values. To realize the learning activities that are appropriate with the disruption era, it is necessary to manage the classroom and management of creative and effective learning.

Classroom management and learning management are two activities that are very closely related but can and must be distinguished from each other because of their different objectives. Instruction includes all activities that are directly intended to achieve the specific objectives of learning (determining the entry behavior of learners, organizing lesson plans, giving information, asking, assessing and other So on). Meanwhile, management/class management can be defined as the skills needed to effectively organize instruction in class [5]. The management objectives of the class according to Doyle are to encourage and build the student's self-control through the process of promoting positive student achievement and behaviour to create academic, teacher, and student behavior [6]. Directly related to school concepts and classroom management. The main purpose of class management is the increase in academic outcomes of students [7]. Classroom management refers to activities that create and maintain optimal conditions for the learning process (coaching "Raport", termination of student behaviour that keeps class attention, granting Reward for timeliness of the assignment by productive group assignments, etc). In other words, in the process of learning teaching in school, there are two groups of problems, namely learning problems and class management problems. 
Class management issues must be addressed with corrective action of management, while learning problems must be addressed with instructional corrective actions. Learners who do not take part in group activities because they feel rejected by other groups (management issues) can not be solved by making activities more interesting (instructional action), although of course indeed It is not disputed that the student's withdrawal will prevent the achievement of the specific purpose of learning to be achieved through the activities of the group in question. Conversely, a good interpersonal relationship between teachers and learners and inter students (a successful management guide) does not by itself guarantee that the learning process will be effective. Effective classroom management is an absolute prerequisite for effective teaching and learning process. Teachers must have teaching skills conducted during the learning process in one of them namely classroom management skills. Teachers and students sometimes feel a different thing in perception, it is a management problem. To minimize management issues to be effective, and promote quality teaching and learning, teachers must be proactive, facilitative and an imaginative class manager [8].

According to Osakwe "effective class management significantly affects climate, motivation, discipline, respect, achievement of goals and academic achievement of students in secondary school systems" [8]. The successful teaching of a teacher is not only directly related to the teaching process, such as clear objectives, mastering the material, choosing the right method, the use of infrastructure, and proper evaluation. Another thing that is not less important is the success of teachers in preventing the onset of student subjects that interfere with the process of teaching learning, the physical condition of learning and the ability to manage it. Therefore, teacher activities can be divided into two, namely learning management activities and class management activities. According to Jennings and Greeberg "Teachers influence their students not only by how and what they teach but also by how they relate, teach and model social and emotional construction, and manage classes" [9].

Unclear learning objectives, overly easy or overly difficult material, material sequences are not systematic, learning tools are unavailable, an example of learning problems. While the subject is sleepy, not on assignment, late in class, disturbing other friends, asking strange questions, seating lots of foul lice, dirty classrooms, is an example of a class management problem. For this reason, a teacher should be able to provide guidance as this will psychologically attract the involvement of learners. The same problem is also felt by Klapayan 3 Elementary School.

Based on the results of observations made by researchers to one of the elementary schools in Klapayan, Geger, Bangkalan, results were obtained, namely classroom management and learning was still felt to be lacking. The classroom management was felt to be lacking because some facilities supporting disrupted era learning were still not available such as LCD and sound systems, the size of the class that was narrow for the number of students was 20/class, student desk arrangements that had never changed, and no supporting facilities such as calendars, picket schedule, wall clock, trash can, etc. Whereas the management of learning experiences constraints on teacher competence which are felt to be lacking, especially in pedagogical competencies. Teachers in Klapayan 3 Elementary school use the lecture method more often without using the media for chasing in delivering material or in other words there are no learning innovations. Though monotonous learning will make students saturated.

The results of this observation were also supported by the statement of the Head of Klapayan 3 Elementary School. He explained that the school in Klapayan, Geger, Bangkalan is a social school aimed at children in rural areas. The operational funds used by the school come from donors and BOS, so that the school has not been able to improve the quality of schools that have competitiveness in the era of disruption. For the teacher, there were found a number of class teachers who were still undergraduates. This is also a factor in ineffective learning activities.

Therefore, in order to support classroom management and learning management activities, a training center for participants is needed for class teachers at Klapayan 3 Elementary School. The implementation of education and training as a solution in improving employee performance, is in accordance with the results of previous researches owned by I Ketut Dartha which states that education and training programs have a simultaneous and partial significant effect on the performance of Malang Regional Secretariat employees [10].

Based on educational problems in the era of disruption being experienced by Klapayan 3 Elementary Schools, the purpose of this study is to provide educators with insight into creative and fun classroom management skills.

\section{METHOD}

The type of research used in this study is descriptive. This research was conducted at Klapayan 3 Elementary School which is located in Geger and carried out on the 3rd until 5th April 2019. The sample in this study was a classroom teacher in Klapayan 3 Elementary School, amounting to 6 class teachers. The data collected consists of primary data including the results of identification of the job description; results of identification of job specification; and secondary data includes school profiles, educator data and education staff, and training data.

The primary data collection technique is done by interviews while secondary data is carried out by interview, discussion, questionnaire, observation, and documentation study. The technique of presenting data in table form is accompanied by structured explanations regarding the criteria for class management and creative management of learning. Data analysis was carried out by referring to the technical analysis of training using a system approach.

\section{RESULTS AND DISCUSSION}

Based on the training activities on the management of creative classes in the era of disruption carried out in Klapayan 3 Elementary School, the results were obtained in the form of criteria / description of the governance of the implementation of creative classroom management activities from each teacher. The results shown are only 8 and can be seen in Table 1 . 
TABLE I. Creative Class Management Creative

\begin{tabular}{|c|l|}
\hline Teacher & \multicolumn{1}{|c|}{ Creative Class Management Creative } \\
\hline 1 & $\begin{array}{l}\text { Classroom furniture arrangements can be moved } \\
\text { according to local conditions or conditions }\end{array}$ \\
\hline 2 & $\begin{array}{l}\text { Students must feel comfortable learning in class by } \\
\text { always keeping clean }\end{array}$ \\
\hline 3 & $\begin{array}{l}\text { Adjust the sitting position of students every day and } \\
\text { adjust to the needs }\end{array}$ \\
\hline 4 & $\begin{array}{l}\text { There is an LCD and projector to make it easier for } \\
\text { teachers to explain }\end{array}$ \\
\hline 5 & $\begin{array}{l}\text { The existence of learning media in the form of globes, } \\
\text { maps, rulers, etc. stored in the classroom cupboard }\end{array}$ \\
\hline 7 & $\begin{array}{l}\text { Large classrooms in proportion to the number of students } \\
\text { nhere is information related to attendance, student } \\
\text { facilities }\end{array}$ \\
\hline 8 & $\begin{array}{l}\text { Classroom layout that must reflect comfort in carrying out } \\
\text { the learning process }\end{array}$ \\
\hline
\end{tabular}

Basically according to Table 1, the class teachers at Klapayan 3 Elementary School have criteria related to the management of creative classes in the era of disruption. Some criteria are very appropriate, just do the execution [11]. However, for facilities that are not yet available, such as learning media and multimedia, namely LCD, Projector, and Sound System, it can be replaced by arranging manageable facilities adjusting the conditions of learning, maintaining cleanliness, arranging student seating positions, and presenting complete class-related information such as attendance, number of students, picket schedule, class management, and class facilities.

The criteria for managing creative learning can be seen in Table II.

TABLE II. CREATIVE LEARNING CRITERIA

\begin{tabular}{|c|c|}
\hline Teacher & Creative Learning Criteria \\
\hline 1 & $\begin{array}{l}\text { Use the method of discussion and experiment in } \\
\text { explaining the material }\end{array}$ \\
\hline 2 & Conduct Cooperative and PBL learning models \\
\hline 3 & Using learning media such as videos, images, etc \\
\hline 4 & Conduct outdor or outside class learning \\
\hline 5 & $\begin{array}{l}\text { Do the game method in learning Do the game method in } \\
\text { learning }\end{array}$ \\
\hline 6 & $\begin{array}{l}\text { Learning is centered on students not teachers so it must } \\
\text { multiply discussion forums between students }\end{array}$ \\
\hline 7 & $\begin{array}{l}\text { The use of learning resources that are not teacher-centered } \\
\text { but the internet and other references. }\end{array}$ \\
\hline 8 & $\begin{array}{l}\text { Creating digital-based learning programs such as E- } \\
\text { learning and blended learning models }\end{array}$ \\
\hline
\end{tabular}

Basically according to Table 2, the class teachers at Klapayan 3 Elementary School have criteria related to the management of creative learning in the era of disruption. Some criteria are very appropriate, just do the execution. However, for learning that uses tools that are not yet available such as learning media and multimedia, namely LCD, Projector, and Sound System, it can be replaced by means of learning outside the classroom, using media that is easily found around the school environment, and applying some approaches, models, and learning methods so that they can eliminate students' boredom while studying.

According to Mulyasa "There are at least three main requirements that must be considered in the development of education so that they can contribute to the improvement of the quality of human resources, namely: (1) building facilities, (2) quality books, (3) teachers and professional education personnel" [12]. The teacher has a very big contribution to the success of learning in school. The teacher is very instrumental in helping the development of students to realize their life goals optimally. In the classroom the teacher carries out two main activities namely teaching activities and classroom management activities. Teaching activities are essentially the process of organizing, organizing the environment around students. All components of teaching which include goals, learning materials, teaching-learning activities, methods, tools and sources, and evaluations are played optimally in order to achieve the predetermined teaching goals before the teaching is carried out.

Class management is not only in the form of class arrangements, physical facilities and routines [13]. Class management activities are intended to create and maintain classroom atmosphere and conditions. So that the teaching and learning process can take place effectively and efficiently. In class all aspects of teaching education meet and process. Teachers with all their abilities, students with all their backgrounds and individual traits. The curriculum with all its components, and the material and learning resources with all the subjects meet and combine and interact in the classroom. Even the results of education and teaching are largely determined by what happens in the classroom. Therefore the class should be managed with, professional, and must be continuous.

In implementing classroom management various inhibiting factors will be encountered. These obstacles can come from the teacher himself, from students, family environment or because of facilities. From the description above, it can be seen that the authority to handle management problems can be classified into three categories, namely :

\section{A. Problems that are Within the Authority of the Teacher}

There are a number of classroom management problems that exist within the scope of the authority of a study teacher to overcome them. This means that a study teacher who is managing the teaching and learning process is required to be able to create, pay attention and restore the learning climate to the conditions of teaching and learning that are beneficial if there is interference, so that students have the opportunity to take optimal benefits from the learning activities they do.

These activities include how to organize the seating of students according to the format of learning, fostering good report cards with students, giving praise, giving gifts (items) to students who complete the task correctly before their time, admonishing students who disturb their friends next to them, reconcile students who fight in ongoing lesson hours to report disciplinary violations by students who have been given a 
warning and warning to the homeroom teacher, headmaster or parents of students.

\section{B. Problems in the Authority of the School}

In the daily reality in the classroom, management problems will be found in which the scope of authority to overcome them is beyond the scope of the subject matter teacher. This problem must be overcome by schools as an educational institution. There may even be management problems that cannot be overcome by only one educational institution but require joint management between schools. In the daily reality in the classroom, management problems will be found in which the scope of authority to overcome them is beyond the scope of the subject matter teacher. This problem must be overcome by schools as an educational institution. There may even be management problems that cannot be overcome by only one educational institution but require joint management between schools.

Problems that are under the authority of the school include the distribution of a fair space for each level or department, the arrangement of flag ceremonies every Monday and if on that day heavy rains, reprimand students who are always late at the apple flag, remind students who do not want to wear school uniforms, advise students with long hair.

\section{Problems that Exist Outside the Authority of the Teacher and the School}

There is still one management problem that is beyond the authority of the subject or school teacher to deal with it. In overcoming this kind of problem, maybe the parents must be involved, institutions that exist in the community such as youth organizations, even the authorities and local government institutions.

These parties are required to also build order through good habituation in the parental supervision house, providing healthy recreational facilities for teenagers and so on. They are also required to address various management issues in case of unwanted things done by learners.

\section{CONCLUSION}

Creative classroom management training at Klapayan 3 Elementary School is conducted for 3 days or $30 \mathrm{JP}$. The training target was 6 class teachers. The material that will be given in the creative classroom management training is (1) understanding of approaches, strategies, methods, tactics, and learning models. (2) creative class management criteria, and (3) creative learning management criteria with a system approach.

For the criteria for creative classroom management, it consists of providing media and multimedia facilities, structuring classroom facilities according to conditions, and maintaining class cleanliness and comfort. while the criteria for managing creative learning consist of the use of several models and methods of learning, digital-based learning such as elearning, and all learning must be student-centered.

In applying creative classroom management, several problems are encountered such as problems that exist within the authority of the teacher, problems that exist in the authority of the school, and problems that exist outside the power of the teacher and the school.

\section{REFERENCES}

[1] T. Kuhn, The structure of scientific revolutions (peran paradigma dalam revolusi sains), Bandung: PT. Remaja rosdakarya, 2005.

[2] B. Handitya. 2018. Peran Pendidikan dalam Membangun Moral Bangsa di Era Disrupsi. Universitas Ngudiwaluyo

[3] J. Kirkley, Principles for Teaching Problem Solving. Plato Learning Center, 2003. [Online]. http://www.plato.com/downloads/papers/paper 04.pdf. [5 Juli 2019].

[4] Festiyed. 2005. Pengembangan Kurikulum Fisika FMIPA UNP Berorientasi Kecakapan Hidup (Life Skill), Makalah Seminar Kurikulum, Pascasarjana UNP Padang

[5] A. Sabanci, G. Ozyildirim, \& R. Imsir. The Effect of ICT Usage on the Classroom. International Review of Social Sciences and Humanit, 7, 2014, pp. 232-245.

[6] W. Doyle. Classroom Organization and Management, "In Mertin C. Wittrock Handbook of Research on Teaching ed.", New York: MacMillan, 2011.

[7] A. O. Omomia. Perceived Impact of Effective Teaching : A Study of Five School In Education District 11, Lagos State, Nigeria. Europian Scientific Journal, 2014, pp. 309-320.

[8] R. N. Osakwe. Classroom Management: A Tool for Achieving Quality Secondary School Education in Nigeria. International Journal of Education, 6, 2014, pp. 58-68.

[9] P. A. Jennings, \& M. T. Greenberg. The Prosocial Classsroom: Teacher Social and Emotional Competence in Relation to Student and Classroom Outcomes, Review of Educational Research, 2009.

[10] I. K. Dartha. 2010. Pengaruh Pendidikan dan Pelatihan (Diklat) terhadap Kinerja Pegawai Negeri Sipil pada Sekretariat Daerah Kota Malang. Malang : Universitas Kanjuruhan Malang.

[11] C. E. Hmelo-Silver. Problem-based learning: What and how do students learn, Educ Psychol Rev, 16 (3) (2004), pp. 235-266.

[12] Mulyasa. 2006. Menjadi Guru Profesional Menciptakan Pembelajaran Kreatif dan Menyenangkan. Bandung: Penerbit PT Remaja Rosdakarya.

[13] A. Rohani. 2004. Pengelolaan Pembelajaran. Jakarta: Rineka Cipta. 